\title{
Nitrogen Fixing and Phosphate Mineralizing Bacterial Communities in Sweet Potato Rhizosphere Show a Genotype-Dependent Distribution
}

\author{
Joana Montezano Marques ${ }^{1}$, Jackeline Rossetti Mateus ${ }^{2}$, Thais Freitas da Silva ${ }^{2}$, \\ Camila Rattes de Almeida Couto ${ }^{2}$, Arie Fitzgerald Blank ${ }^{3}$ and Lucy Seldin ${ }^{2, *(1)}$ \\ 1 Instituto de Ciências Biológicas, Centro de Genômica e Biologia de Sistemas, Universidade Federal do Pará, \\ Av. Augusto Corrêa, 01, Guamá, CEP 66.075-110, Belém, PA, Brazil; jomontezanomarques@gmail.com \\ 2 Instituto de Microbiologia Paulo de Góes (IMPPG), Universidade Federal do Rio de Janeiro, Centro de \\ Ciências da Saúde, Bloco I, Ilha do Fundão, CEP 21941-590, Rio de Janeiro, RJ, Brazil; \\ jacky.rossetti@gmail.com (J.R.M.); thaisfs.bio@gmail.com (T.F.d.S.); camilarattes@gmail.com (C.R.d.A.C.) \\ 3 Departamento de Engenharia Agronômica, Universidade Federal de Sergipe, Av. Marechal Rondon S/N, \\ CEP 49100-000, São Cristóvão, SE, Brazil; arie.blank@gmail.com \\ * Correspondence: 1seldin@micro.ufrj.br; Tel.: +55-213-938-6741; Fax: +55-212-560-8344
}

Received: 23 October 2019; Accepted: 28 November 2019; Published: 3 December 2019

\begin{abstract}
We hypothesize that sweet potato genotypes can influence the bacterial communities related to phosphate mineralization and nitrogen fixation in the rhizosphere. Tuberous roots of field-grown sweet potato from genotypes IPB-149, IPB-052, and IPB-137 were sampled three and six months after planting. The total community DNA was extracted from the rhizosphere and analyzed by Polymerase Chain Reaction-Denaturing Gradient Gel Electrophoresis (PCR-DGGE) and quantitative real-time PCR (qPCR), based on the alkaline phosphatase coding gene (alp gene) and on the nitrogenase coding gene (nifH gene). The cluster analysis based on DGGE showed that plant age slightly influenced the bacterial community related to phosphate mineralization in the rhizosphere of IPB-137, although it did not affect the bacterial community related to nitrogen fixation. The statistical analysis of DGGE fingerprints (Permutation test, $p \leq 0.05$ ) showed that nitrogen-fixing bacterial community of IPB-052 statistically differed from genotypes IPB-149 and IPB-137 after six months of planting. The bacterial community of IPB- 137 rhizosphere analyzed by alp gene also showed significant differences when compared to IPB-149 in both sampling times ( $p \leq 0.05)$. In addition, alp gene copy numbers significantly increased in abundance in the rhizosphere of IPB-137 after six months of planting. Therefore, plant genotype should be considered in the biofertilization of sweet potato.
\end{abstract}

Keywords: sweet potato; bacterial communities; nitrogen fixation; phosphate mineralization; plant genotype

\section{Introduction}

The rhizosphere is characterized as the soil in close contact with plant roots and is where the root microbiome recruitment occurs through exudation of plant molecular signals, especially secondary metabolites [1,2]. Plants are usually benefited by the interactions with soil microbes in their rhizospheres, improving plant nutrient acquisition, pathogen resistance, and stress tolerance [3,4]. The so-called 'Plant Growth-Promoting Rhizobacteria' (PGPR) are non-pathogenic bacteria that live in the rhizosphere soil and are able to promote plant development [3,5-7]. Some PGPR are able to provide essential nutrients to plants using a compound that is synthesized by the bacterium or making some macro and micro-nutrients available that were immobilized in mineral and organic compounds, and were not free 
for plant uptake [8]. The biological nitrogen fixation and the phosphate solubilization/mineralization are examples of the direct promotion of plant growth by PGPR [9]. The use of PGPR in biofertilization is an open field for research on sustainable agriculture, as it optimizes crop yields based on beneficial plant-microbe interactions [1,10]. The use of PGPR has been tested with success in different plants such as maize, potato, wheat, and many other economically important ones [11].

A large number of biotic and abiotic factors influence the microbial communities in the rhizosphere. Physicochemical characteristics of the soil directly modulate microbial communities [2] and plant physiology and genetics also control rhizosphere composition $[1,12]$. The impact of plant genotypes on rhizosphere microbiome composition varies depending on soil context and plant species studied [13]. Therefore, understanding mutual adaptation between microbes and plants in response to different environmental conditions can contribute to crop breeding and management programs.

Sweet potato plants (Ipomoea batatas L.) present a complex root system composed by fibrous roots specialized in nutrient absorption - and tuberous roots - specialized in nutrient storage. The transition from fibrous root to tuberous root is related to starch accumulation $[14,15]$. The tuberous roots represent one of the major nutrient sources for countries in development, and they also contribute to a supply of vitamins B, C, and E and minerals, including iron, calcium, zinc, and selenium, in the human diet (International Potato Center - [16]). Sweet potato is cultivated worldwide, with Asia and Africa together producing $95 \%$ of all roots commercialized globally [17]. Sweet potato is used for food, animal feed, and processing (as food, starch, and other products) and its biggest global producer and consumer is China. Among Latin America countries, Brazil is in the spotlight as the main sweet potato producer. Sweet potato is considered to be the country's fourth most consumed vegetable crop, and in the northeast of the country, the culture is important both economically and socially [18].

For sweet potato, as for other crops, high root yields are desirable for good crop productivity. Usually, chemical fertilizers are used, but the high inorganic fertilizer input contributes negatively to production costs and to environment pollution [19]. They are expensive, non-eco-friendly, cause eutrophication, reduce organic matter and microbial activity in soil, and are hazardous to health [20]. Therefore, there is increasing interest in the use of biofertilizers for sustainable agriculture. PGPR can help to increase quality of the soil by providing nutrients required for benefit of the plants [8]. Dawwam, et al. [21] have already demonstrated the beneficial effect of PGPR isolated from the roots of sweet potato. Different isolates having abilities for IAA production and phosphate solubilization were tested as bioinoculants to potato tubers, and the inoculated plants showed significant differences in various parameters such as vegetative growth, photosynthetic pigments, and N, $\mathrm{P}$, and $\mathrm{K}$ concentrations.

According to other studies, the growth of sweet potato can be significantly improved by PGPR [19,22-24]. However, information about the PGPR communities during the sweet potato growth and their behavior depending on the genotype of sweet potato studied is still limited. In previous studies, the total bacterial communities from the rhizosphere and endosphere of the tuberous roots of three sweet potato genotypes (IPB-149, IPB-137, and IPB-052) were characterized by Marques, et al. $[12,25]$. The results showed a strong rhizosphere effect in the soil surrounding the sweet potato tuberous roots, showing an influence of plant age and genotypes in bacterial communities. However, the effects of either plant age or genotypes specifically in the PGPR communities (nitrogen fixing and phosphate mineralizing bacteria) found in the rhizosphere of these sweet potato genotypes have never been described before. Therefore, in the present study, we used cultivation-independent methods (PCR-DGGE and quantitative PCR) based on alp gene (alkaline phosphatase coding gene) and on nifH gene (nitrogenase coding gene) to analyze the structure and the density (gene copy numbers) of the bacterial communities related to biofertilization (phosphate mineralization and nitrogen fixation) in rhizosphere soil. The analyses were performed to compare the distribution of alp and nifH genes among the sweet potato genotypes sampled three and six months after planting. The data generated in this study could be important for increasing knowledge on the productivity of these sweet potato genotypes under field conditions. 


\section{Materials and Methods}

\subsection{Plant Genotypes, Experimental Field Design and Conditions}

The sweet potato genotypes IPB-149, IPB-137, and IPB-052 used in the present study are from the Active Germplasm Bank of the Federal University of Sergipe (UFS). These genotypes were previously described by Marques, et al. [12,25]. In brief, the IPB-149 genotype, the most commercialized genotype in the northeast of Brazil, presents a white surface color in the tuberous roots, a high starch content, and a major resistance to insect attack. The IPB-052 genotype, commercially known as cultivar Brazlândia Rosada, shows similar characteristics to the IPB-149 genotype. In contrast, the IPB-137 genotype, from the breeding program of the Federal University of Lavras, Brazil and denoted as clone 2007HSF028-08, presents different characteristics, including a pink color on its tuberous root surface, a lower starch content, and a low resistance to insect attack. It has longer branches and a shorter length between nodes, and the use of its aerial part for animal feed purposes has been suggested. Other morpho-agronomic traits, including the dry mass of aboveground part and the total productivity of the roots, were presented in Alves, et al. [26].

In 2011, a field experiment with sweet potato plants was performed in the Research Farm "Campus Rural da UFS". The experimental farm is located in the 'São Cristóvão' municipality (1055'27" S/ $\left.37^{\circ} 12^{\prime} 01^{\prime \prime} \mathrm{W}\right)$, Sergipe State, northeast of Brazil. The experimental farm soil characteristics were: $\mathrm{pH}$ (5.4), $\mathrm{Ca}^{2+}\left(0.82 \mathrm{cmolc} / \mathrm{dm}^{3}\right), \mathrm{Mg}^{2+}\left(0.43 \mathrm{cmolc} / \mathrm{dm}^{3}\right), \mathrm{Al}^{3+}\left(0.65 \mathrm{cmolc} / \mathrm{dm}^{3}\right), \mathrm{Na}\left(3.5 \mathrm{mg} / \mathrm{dm}^{3}\right)$, $\mathrm{K}\left(21.1 \mathrm{mg} / \mathrm{dm}^{3}\right), \mathrm{P}\left(7.0 \mathrm{mg} / \mathrm{dm}^{3}\right), 73.82 \%$ sand, $20.72 \%$ silt, $5.46 \%$ clay, and $0.86 \% \mathrm{C}_{\text {org }}$ [14-16]. The experimental field design was described in Marques, et al. [12,25]. The genotypes were planted in three replicate rows (randomized block design) in the experimental plot with spaces of $0.8 \mathrm{~m}$ between the rows and $0.35 \mathrm{~m}$ between plants. All of the cultural management processes used were those described in Alves, et al. [26]. After three (t1,_3M) and six (t2,_6M) months, sweet potato plants with similar plant growth developmental stages were randomly harvested from the research farm soil. A total of five plants/replicates of the three different sweet potato genotypes were collected in each sampling time. Their roots were shaken to remove the loosely attached soil, and the soil still adhering to the tuberous roots was aseptically brushed off from all tuberous roots of every plant. This soil was considered to be rhizosphere soil. The rhizosphere samples were kept at $-20^{\circ} \mathrm{C}$ before total community DNA (TC-DNA) extraction.

\subsection{TC-DNA Extraction and PCR Amplification}

The TC-DNA was extracted from each five replicates of rhizosphere $(0.5 \mathrm{~g}$ of each) from the three sweet potato genotypes (IPB-149, IPB-137, and IPB-052), and from both sampling times ( $\mathrm{t} 1$ and $\mathrm{t} 2$ ). The Fast DNA Spin Kit for soil (Qbiogene, BIO 101 Systems, Carlsbad, CA, USA) was used according to the manufacturer's instructions. TC-DNA preparations were used in PCR reactions in order to amplify the alp gene (alkaline phosphatase coding gene) and nifH gene (nitrogenase coding gene).

The PCR conditions for alp gene amplification were performed as described by Sakurai, et al. [27]. The primers ALPS-F730/ALPS-R1101 were used in the PCR reactions and the reverse primer was added with a GC clamp. The reaction conditions were those previously described in Sakurai, et al. [27]. Fragments of the nifH gene were amplified using a nested-PCR approach. Briefly, the primers FGPH19 [28] and PolR [29] were used for the first-round of the PCR. The first-round PCR conditions were those described by Monteiro, et al. [30]. A 1:100 dilution of the first-round PCR product was used as a template for the second-round with the primers PolF/AQER using the same reaction conditions as described by Poly, et al. [29]. The PCR products were visualized by electrophoresis and then stored at $-20{ }^{\circ} \mathrm{C}$ until DGGE analyses.

\subsection{DGGE and Statistical Analyses}

The INGENYphorU-2 system (INGENY International BV, Middelburg, The Netherlands) was used for DGGE. The PCR products from both genes (alp and nifH) and a standard bacterial marker 
(previously described by Heuer, et al. [31]) were loaded directly to DGGE. The denaturing gradient of urea and formamide varied in the range $40 \%-60 \%$ (the alp gene), and $40 \%-70 \%$ (the nifH gene). The electrophoresis conditions were performed as described by Sakurai, et al. [27] and Monteiro, et al. [30] for the alp and the nifH genes, respectively. After electrophoresis, the DGGEs were stained with SYBR Green I and visualized using a STORM apparatus (Amersham Pharmacia Biotech, Munich, Germany). The unweighted pair group with average linkages (UPGMA) was used for cluster analysis. The software BioNumerics 5.0 version (Applied Mathematics, Kortrijk, Belgium) was used to construct dendrograms based on Pearson similarity indices. Significant differences $(p \leq 0.05)$ between DGGE profiles were determined by permutation tests based on pairwise Pearson correlation indices using the PERMTEST software [32]. In addition, quantitative matrices generated from the DGGE lanes based on Dice correlation index were exported to PAST software [33] for principal component analysis (PCA).

\subsection{Determination of alp and nifH Genes Copy Numbers}

The abundance of phosphate mineralizing and nitrogen fixing bacteria were quantified by targeting the alp and nifH genes, respectively, in a quantitative real-time PCR (qPCR). The reactions were performed in an ABI Prism 7300 Cycler (Applied Biosystems, Germany) in $25 \mu \mathrm{L}$ reaction mixtures containing $1 \times \mathrm{SYBR}^{\mathrm{TM}}$ Select Master Mix (Applied Biosystems, Germany), $0.4 \mu \mathrm{g} / \mu \mathrm{L}$ BSA, $1 \mu \mathrm{L}$ of target DNA (approximately $50 \mathrm{ng}$ ) and $0.5 \mu \mathrm{M}$ of primers. For the quantification of alp gene, primers ALPS-F730/ALPS-R1101 [27] were used. The amplification conditions were 2 min at $50{ }^{\circ} \mathrm{C}$, $10 \mathrm{~min}$ at $95^{\circ} \mathrm{C}$, and 40 cycles consisting of $30 \mathrm{~s}$ at $95^{\circ} \mathrm{C}, 60 \mathrm{~s}$ at $57^{\circ} \mathrm{C}$, and $30 \mathrm{~s}$ at $72{ }^{\circ} \mathrm{C}$. Standard curves were prepared by serial dilutions (from $10^{8}$ to $10^{1}$ gene copy numbers $/ \mu \mathrm{L}$ ) of plasmid DNA (pTZ57R/T; CloneJET TM PCR Cloning Kit - Thermo Fisher Scientific, Waltham, MA, USA) containing the cloned alp gene PCR products from bacterial strain 006.30 [34]. For the quantification of the nifH gene, primers FGPH19 [28] and PolR [29] were chosen as described by Taketani, et al. [35]. The amplification conditions were an initial denaturation step at $94^{\circ} \mathrm{C}$ for $10 \mathrm{~min}$, followed by 40 cycles of $1 \mathrm{~min}$ at $94{ }^{\circ} \mathrm{C}$, $27 \mathrm{~s}$ at $57^{\circ} \mathrm{C}$, and $1 \mathrm{~min}$ at $72^{\circ} \mathrm{C}$. Standard curves were obtained using serial dilutions of the Escherichia coli-derived vector plasmid JM109 (Promega, Madison, WI, USA) containing a cloned nifH gene from Bradyrhizobium liaoningense, using $10^{2}$ to $10^{7}$ gene copies/ $\mu$ L. Significant differences between samples were tested in pairwise comparisons using the Tukey test ( $p \leq 0.05$; SAS 9.3; SAS Institute Inc., Cary, NC, USA).

\section{Results}

\subsection{Structure of Phosphate Mineralizing and Nitrogen Fixing Bacterial Communities Analyzed by DGGE}

The effects of plant growth stage and genotypes on the structure of the phosphate mineralizing and nitrogen fixing bacterial communities present in the rhizosphere of tuberous roots of the genotypes IPB-149, IPB-137, and IPB-052 were analyzed by DGGE based on alp gene and nifH gene fragments, respectively, which were amplified from TC-DNA.

For the DGGE profiles based on the alp gene, principal component analysis (PCA) showed the formation of two separate groups: IPB-137_6M and IPB-149_3M (Figure 1A). The fingerprints of the phosphate mineralizing bacterial community in the rhizosphere were statistically analyzed using the permutation test $(p \leq 0.05)$. The sampling time had a significant effect on the structure of the bacterial community in the IPB-137 genotype (Table 1). Moreover, the results showed that the genotypes also significantly influenced the structure of the phosphate mineralizing bacterial community in IPB-137 and IPB-149 (Figure 1B). These communities were statistically different for both sampling times (Table 1). Therefore, the different genotypes and, to a minor extent, the time influenced the phosphate mineralizing bacterial community present in the tuberous roots of sweet potato studied here. The DGGE fingerprint analyses showed that the structure of both bacterial communities were complex with high variability among the replicates (Figure S1A,B). The samplings of IPB-137 and of 
IPB-149 were grouped separately (per genotype) with more than $60 \%$ similarity after UPGMA cluster analysis (Figure S1A). A high similarity (more than 80\%) was observed within IPB-137_6M samples, suggesting a slight influence of the plant age, as was observed in PCA.

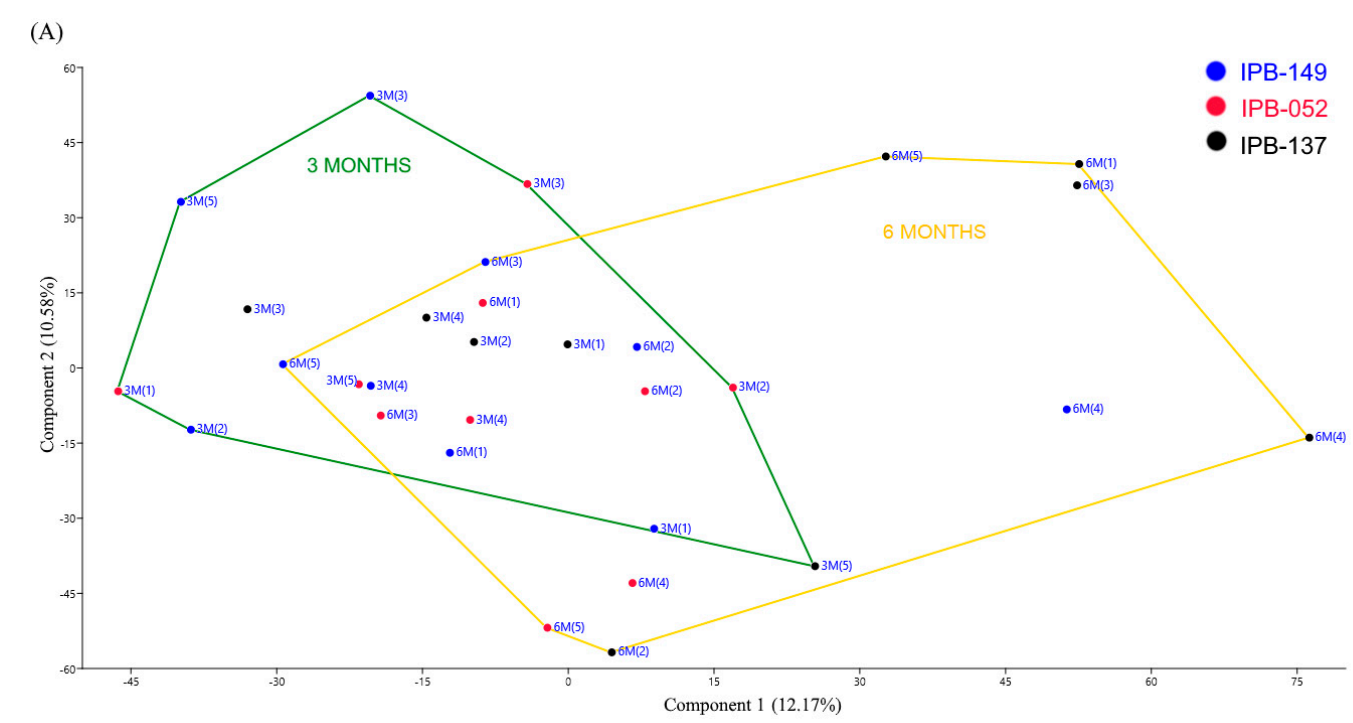

(B)

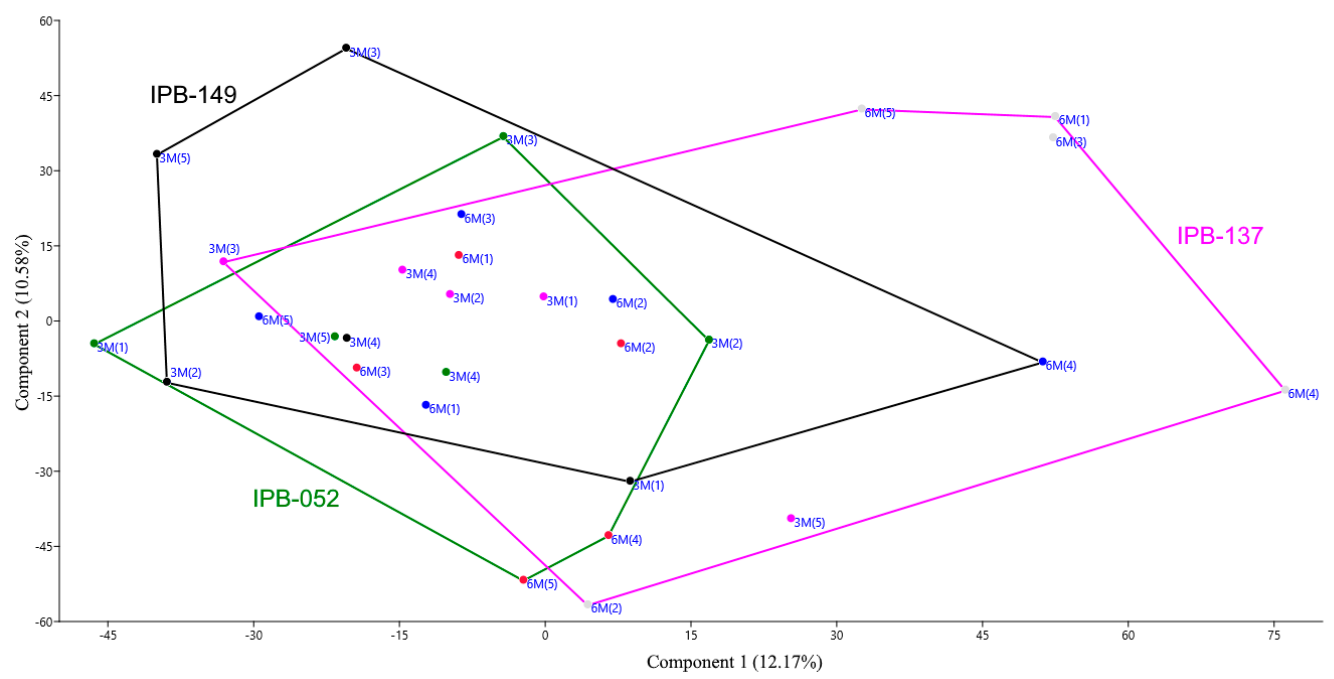

Figure 1. Principal component analyses (PCA) was conducted using Denaturing Gradient Gel Electrophoresis (DGGE) patterns of phosphate mineralizing bacteria based on the alp gene from the rhizosphere of three different sweet potato genotypes (IPB-149, IPB-137, and IPB-052) sampled after three and six months after planting ( $\mathrm{t} 1, \ldots 3 \mathrm{M}$ and $\mathrm{t} 2, \_6 \mathrm{M}$, respectively). (A) and (B) highlight the grouping observed within the sampling time $(\mathrm{t} 1 \times \mathrm{t} 2)$ and within the different genotypes, respectively.

For the DGGE profiles based on nif gene, the influence of the sampling time was not evident in PCA, except for some of IPB-137_6M replicates (Figure 2A). The results also showed that the genotypes affected the structure of the nitrogen fixing bacterial community (Figure 2B). The fingerprints of the nitrogen fixing bacterial community in the rhizosphere were statistically analyzed using the permutation test $(p \leq 0.05)$. No significant effect of the sampling time on the structure of the nitrogen fixing bacterial community within the different genotypes was observed (Table 1). In contrast, the structure of the nitrogen fixing bacterial communities in sweet potato genotypes IPB-149 and IPB-137 were statistically different from those in IPB-052 after six months of planting (Table 1). The visual interpretation of the DGGE profiles corroborated the PCA. UPGMA cluster analysis of the DGGE profiles based on 
nifH gene showed a high similarity within the replicates of IPB-137_6M. The replicates of IPB-052_6M formed a group that was separate from the other genotypes (Figure S1B).

Table 1. Dissimilarity ( $\mathrm{d}$ value in \%) of rhizosphere bacterial fingerprints (DGGE) based on alp and nifH genes with comparisons between samplings ( $\mathrm{t} 1, \_3 \mathrm{M}$ and $\left.\mathrm{t} 2, \_6 \mathrm{M}\right)$ or among IPB-149, IPB-137, and IPB-052 genotypes.

\begin{tabular}{|c|c|c|c|c|c|c|}
\hline Genes & $\begin{array}{l}\text { Sampling Time } \\
(\mathbf{t} 1 \times \mathrm{t} 2)\end{array}$ & Dissimilarity (\%) & Genotypes (t1) & Dissimilarity (\%) & Genotypes (t2) & Dissimilarity (\%) \\
\hline \multirow[t]{2}{*}{ alp } & IPB-149 & 0.7 & IPB-149 × IPB-137 & $8.1^{*}$ & IPB-149 × IPB-137 & $17.6^{*}$ \\
\hline & IPB-137 & $0.4^{*}$ & IPB-149 × IPB-052 & 0.2 & IPB-149 × IPB-052 & 3.1 \\
\hline \multirow[t]{3}{*}{ nifH } & IPB-149 & -1.9 & IPB-149 × IPB-137 & -1.8 & IPB-149 × IPB-137 & 9.0 \\
\hline & IPB-137 & 18.3 & IPB-149 × IPB-052 & 0.4 & IPB-149 × IPB-052 & $11.0^{*}$ \\
\hline & IPB-052 & 12.4 & IPB-137 × IPB-052 & 1.6 & IPB-137 × IPB-052 & $26.8^{*}$ \\
\hline
\end{tabular}

* Significant difference $(p \leq 0.05)$ as determined using the permutation test.

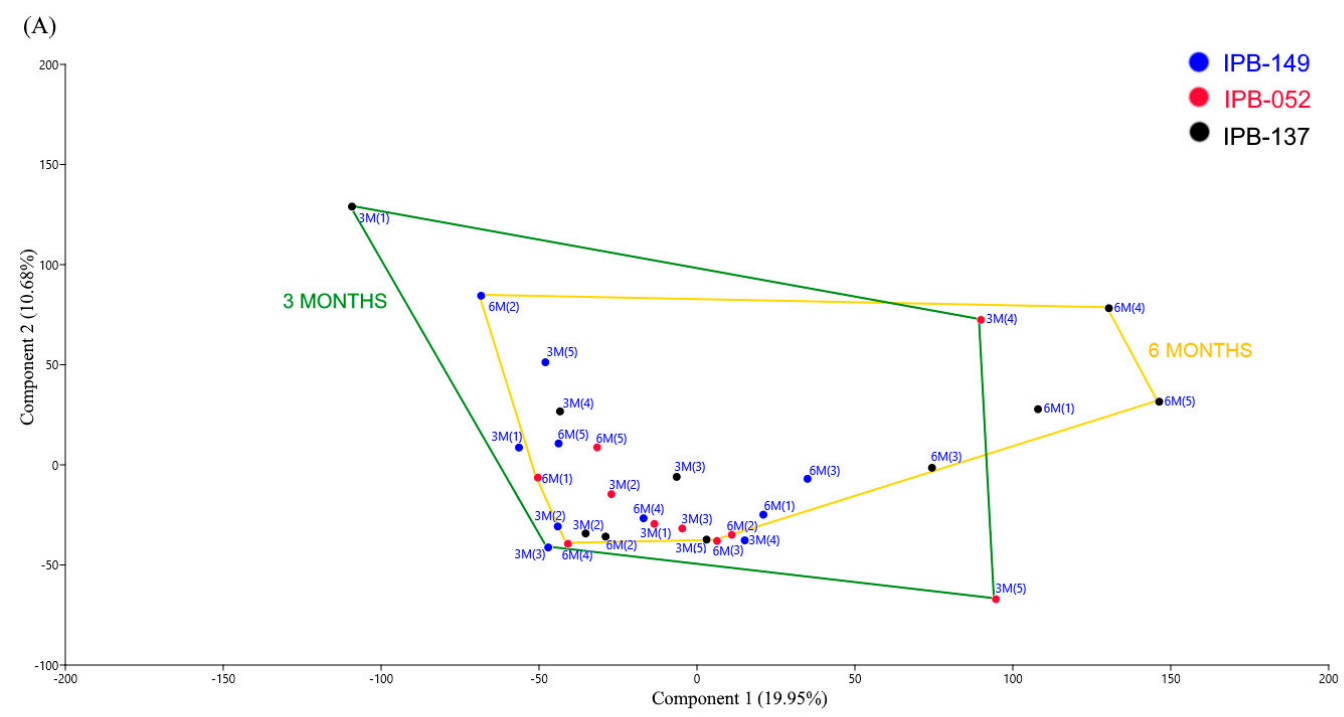

(B)

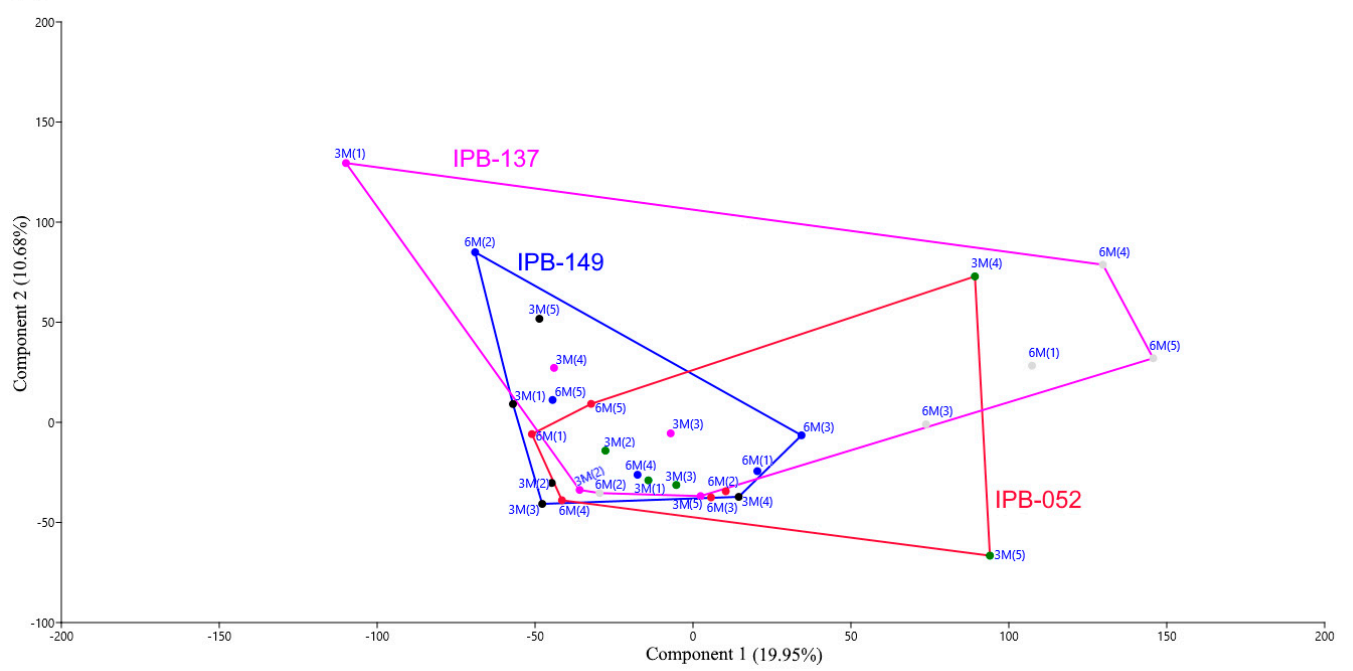

Figure 2. Principal component analyses (PCA) were conducted using DGGE patterns of nitrogen fixing bacteria based on the nifH gene from the rhizosphere of three different sweet potato genotypes (IPB-149, IPB-137, and IPB-052) sampled after three and six months after planting (t1,_3M and t2,_6M, respectively). (A) and (B) highlight the grouping observed within the sampling time ( $\mathrm{t} 1 \mathrm{x} \mathrm{t} 2)$ and within the different genotypes, respectively. 


\subsection{Quantitative Real-time PCR of alp and nifH Genes}

The alp and nifH genes were quantified in all sweet potato rhizospheres. The values for alp gene quantification (copies of alp gene/g of rhizosphere soil) were higher than for nifH gene (Figure 3). The analyses revealed a statistically significant difference $(p \leq 0.05)$ in the abundance levels of the alp genes only in IPB-137 after six months of planting, suggesting that the abundance of the phosphate mineralizing bacterial community present in the tuberous roots of sweet potato is influenced by the genotype and also by the time in IPB-137 (Figure 3A). Similarly, the IPB-137 genotype showed statistically significant differences in the abundance levels of the nifH genes between three and six months $(\mathrm{t} 1 \times \mathrm{t} 2)$ after planting (Figure 3B). Statistically similar nifH gene densities $(p \leq 0.05)$ were observed between the $\mathrm{t} 1$ and $\mathrm{t} 2$ samplings in IPB-149 and IPB-052. When comparing the $\mathrm{t} 2$ samplings, no differences in nifH gene densities were observed between the different genotypes (Figure 3B).

$$
\begin{aligned}
& \text { (A) } \\
& 1 \times 10^{6}
\end{aligned}
$$

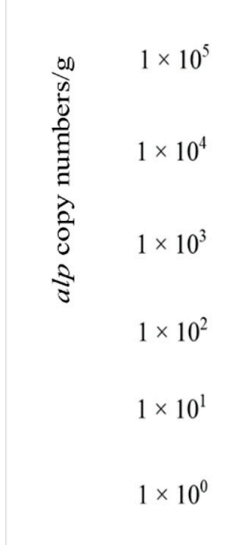

$$
1 \times 10^{7}
$$$$
\text { (2) }
$$

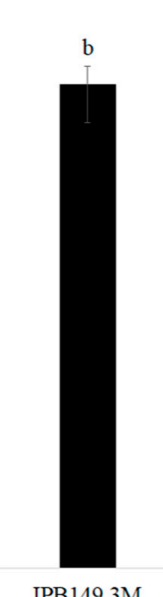

IPB149 3M

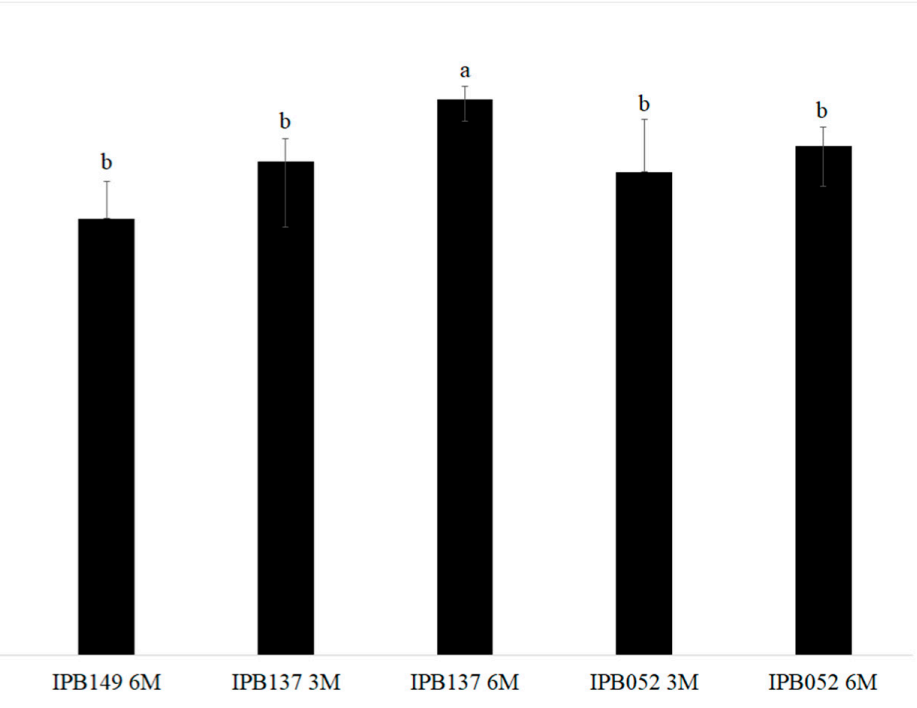

(B)

$$
1 \times 10^{4}
$$

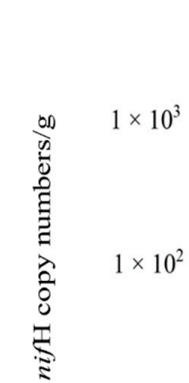

$$
1 \times 10^{1}
$$

$1 \times 10^{0}$

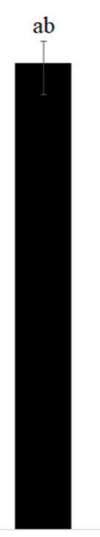

IPB149 3M
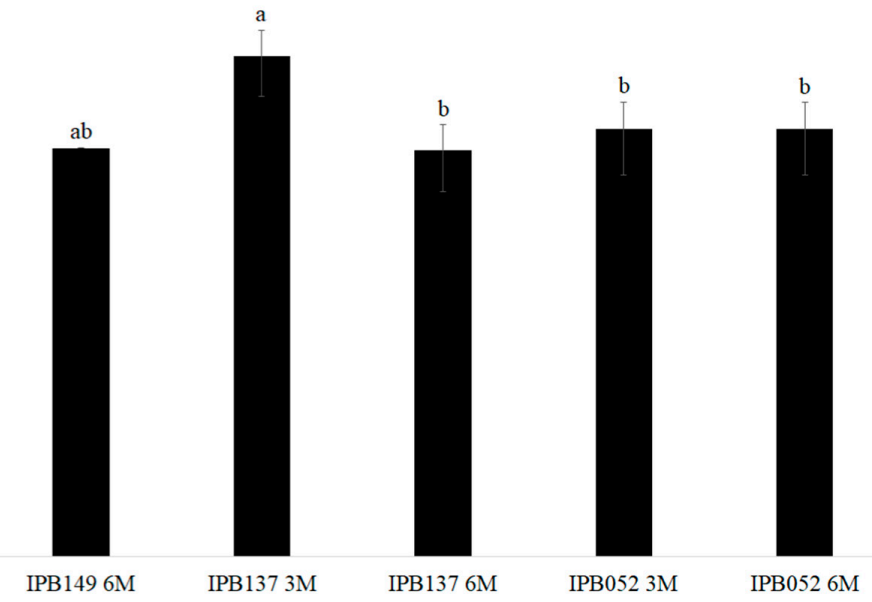

Figure 3. Abundance of bacterial phosphate mineralizing bacteria based on the alp gene (A) and nitrogen fixing bacteria based on the nifH gene $(\mathbf{B})$ in the rhizosphere of three different sweet potato genotypes (IPB-149, IPB-137 and IPB-052) sampled after three and six months after planting (t1,_3M and $t 2, \_6 M$, respectively). The error bars indicate standard error. Different letters (a and $b$ ) indicate significant differences of means in pairwise comparisons (Tukey test; $p \leq 0.05$ ). 


\section{Discussion}

The use of biofertilizers, including plant growth promoting bacteria, is increasing worldwide as an environmentally-friendly alternative for soil fertility management, sustaining not only sweet potato yields (both in terms of tuber weight and in terms of the levels of starch in sweet potato crops) but also different economically important plants [11], compared with the continuous application of inorganic fertilizers alone [36-39]. The plant positive response to biofertilization stimulates the continuous optimization of crop yields by exploiting beneficial plant-microbe interactions [4]. However, the effect of different biofertilizers on root colonization, nutrient uptake, growth, and yield is not always as effective as expected. Different types of soils found in various countries, as well as plant genotypes and the sampling time (period the crop was maintained in the field) all contribute to different responses in plant yields, including those observed in sweet potato [22,36,37].

It was evident in previous studies conducted by our group that the total bacterial communities associated with different genotypes of sweet potato planted in Brazil varied depending on the plant age and genotype $[12,25]$. However, the behavior of specific communities such as phosphate mineralizers and nitrogen fixers, which may contribute directly to the plant development, was not taken into account at that time. Indeed, the majority of the studies focusing on phosphate-solubilizing/mineralizing and nitrogen-fixing bacterial communities found in the literature were conducted to screen for beneficial traits that could improve plant growth. Alterations on the structure and abundance of these communities along the plant growth have not been accessed, which are usually restricted to a single genotype and a growth stage of the plant $[21,24,40]$.

In the present study, we demonstrated that the structure of phosphate- mineralizing bacterial community (based on the presence of alp genes) varied along the plant growth depending on the genotype considered. The structure of the phosphate mineralizing bacterial community in IPB-137 was mainly different from that in IPB-149. Tarafdar and Jungk [41] observed that both acid and alkaline phosphatase activities of soil were usually increased near the rhizoplane of different plants and such an increase depended on plant species, soil type, and plant age. Although the optimal $\mathrm{pH}$ for the activity of the alkaline phosphatase is higher than the $\mathrm{pH}$ of the soil where the sweet potatoes were planted, its role remains an important one regardless. For example, both acid and alkaline phosphatase activities near the rhizoplane of maize resulted in alterations of the composition of bacterial communities, as determined by PCR-DGGE [42]. In addition to the influence of the genotype, a statistically difference in phosphate mineralizing bacterial communities in IPB-137 was observed between samplings after three to six months of planting. Changes were observed not only in the structure of this community but also in the abundance of alp genes after six months of growth. These changes could be explained by the fact that, at the late growth stage of sweet potato, the roots usually presented stronger nutrient absorption ability due to the increase of the number of root tips, the enlargement of root surface area, and the root volume [43]. Phosphate mineralizers may have contributed to the conversion of insoluble phosphates into available forms for plant via different processes such as acidification, exchange reactions, chelation, and production of gluconic acid [21,44].

Nitrogen-fixing bacteria identified as Azospirillum sp. were first isolated from the fibrous roots and storage root peels of sweet potato [45]. From this time on, different studies were carried out on the isolation and identification of nitrogen fixers in sweet potato roots, as important evidence indicated that nonsymbiotic $\mathrm{N}_{2}$ fixation in sweet potato is agronomically significant [40]. Active expressions of the nifH gene phylogenetically similar to those of Bradyrhizobium spp., Sinorhizobium sp., Azorhizobium sp., Bacillus sp. and Pelomonas sp. were found in large quantities in the $\mathrm{N}_{2}$-fixing sweet potato storage tubers planted in different regions $[40,46,47]$. In our study, the structure and abundance of nitrogen-fixing bacterial communities based on the nifH gene were determined and compared between the three genotypes.

The nitrogen-fixing bacterial community in the rhizosphere of IPB-052 seems to be different from those of the other two genotypes. IPB-052 presents a white surface color on the tuberous roots and high starch content. It is quite possible that specific nitrogen-fixing bacteria are being recruited from 
soil to the rhizosphere. This rhizosphere effect can generate a zone with maximum microbial activity, resulting in a pool of metabolic products that can support plant growth [48]. However, the difference observed on the structure of the nitrogen-fixing bacterial community in IPB-052 does not also appear in the analysis of the nifH gene abundance. The nifH gene copy numbers appeared to be lower than those of alp genes, and the only difference observed among the genotypes studied was between the 3-6 month samplings in IPB-137. This fact suggests that nitrogen-fixing bacteria may only contribute more towards plant development during the early stages of plant growth in this sweet potato genotype.

\section{Conclusions}

The results obtained here suggest that the three sweet potato genotypes studied showed a differentiated recruitment of members of the studied communities (phosphate mineralizers and nitrogen fixers). In addition, the IPB-137 genotype showed the highest number of copies of both genes studied with statistically significant differences compared to the other genotypes. Even though we know that the distribution of these communities may be directly related to the productivity of a given genotype, more studies are needed to trace this correlation in the field.

Supplementary Materials: The following are available online at http://www.mdpi.com/1424-2818/11/12/231/s1, Figure S1. DGGE fingerprints and UPGMA cluster analyses based on alp gene fragments (A) and nifH gene fragments (B) of phosphate mineralizing and nitrogen fixing bacterial communities, respectively, present in the rhizosphere of the tuberous roots (replicates 1-5 in parenthesis) from three different sweet potato genotypes (IPB-149, IPB-137 and IPB-052) sampled three (t1,_3M - black squares) and six (t2,_6M - grey squares) months after planting.

Author Contributions: Conceptualization, L.S. and J.M.M.; Data curation, A.F.B. and J.M.M.; Formal analysis, C.R.d.A.C., J.M.M., J.R.M., T.F.d.S. and L.S.; Funding acquisition, L.S.; Methodology, C.R.d.A.C., J.M.M., J.R.M. and T.F.d.S.; Project administration, L.S.; Resources, A.F.B.; Supervision, L.S.; Writing-original draft, J.M.M. and L.S.; Writing-review \& editing, A.F.B., C.R.d.A.C., J.M.M., J.R.M., T.F.d.S. and L.S.

Funding: Coordenação de Aperfeiçoamento de Pessoal de Nível Superior: 01; Conselho Nacional de Desenvolvimento Científico e Tecnológico; Fundação Carlos Chagas Filho de Amparo à Pesquisa do Estado do Rio de Janeiro.

Acknowledgments: The authors thank Simone Cotta for her help in qPCR experiments. This study was financially supported by the National Research Council of Brazil (CNPq), Fundação de Amparo à Pesquisa do Estado do Rio de Janeiro (FAPERJ) and Coordenação de Aperfeiçoamento de Pessoal de Nível Superior (CAPES).

Conflicts of Interest: The authors declare that they have no conflict of interest.

\section{References}

1. Berendsen, R.L.; Pieterse, C.M.J.; Bakker, P.A.H.M. The rhizosphere microbiome and plant health. Trends Plant Sci. 2012, 17, 478-486. [CrossRef] [PubMed]

2. Philippot, L.; Raaijmakers, J.M.; Lemanceau, P.; van der Putten, W.H. Going back to the roots: The microbial ecology of the rhizosphere. Nat. Rev. Microbiol. 2013, 11, 789-799. [CrossRef] [PubMed]

3. Dutta, S.; Podile, A.R. Plant growth promoting rhizobacteria (PGPR): The bugs to debug the root zone. Crit. Ver. Microbiol. 2010, 36, 232-344. [CrossRef]

4. Liu, F.; Hewezi, T.; Lebeis, S.L.; Pantalone, V.; Grewal, O.S.; Staton, M.E. Soil indigenous microbiome and plant genotypes cooperatively modify soybean rhizosphere microbiome assembly. BMC Microbiol. 2019, 19, 201. [CrossRef] [PubMed]

5. Babalola, O.O. Beneficial bacteria of agricultural importance. Biotechnol. Lett. 2010, 32, 1559-1570. [CrossRef]

6. Kloepper, J.W.; Lifshitz, R.; Zablotowicz, R.M. Free-living bacterial inocula for enhancing crop productity. Trends Biotechnol. 1989, 7, 39-43. [CrossRef]

7. Vejan, P.; Abdullah, R.; Khadiran, T.; Ismail, S.; Nasrulhaq Boyce, A. Role of Plant Growth Promoting Rhizobacteria in Agricultural Sustainability—A Review. Molecules 2016, 21, 573. [CrossRef]

8. Egamberdieva, D.; Lugtenberg, B. Use of plant growth-promoting rhizobacteria to alleviate salinity stress in plants. In Use of Microbes for the Alleviation of Soil Stresses; Miransari, M., Ed.; Springer: New York, NY, USA, 2014; pp. 73-96. 
9. Glick, B.R. The enhancement of plant growth by free-living bacteria. Can. J. Microbiol. 1995, 41, $109-117$. [CrossRef]

10. Schlaeppi, K.; Bulgarelli, D. The plant microbiome at work. Mol. Plant Microbe Interact. 2015, 28, $212-217$. [CrossRef]

11. Souza, R.; Ambrosini, A.; Passaglia, L.M.P. Plant growth-promoting bacteria as inoculants in agricultural soils. Genet. Mol. Biol. 2015, 38, 401-419. [CrossRef]

12. Marques, J.M.; da Silva, T.F.; Vollú, R.E.; Blank, A.F.; Ding, G.-C.; Seldin, L.; Smalla, K. Plant age and genotype affect the bacterial community composition in the tuber rhizosphere of field-grown sweet potato plants. FEMS Microbiol. Ecol. 2014, 88, 424-435. [CrossRef] [PubMed]

13. Pérez-Jaramillo, J.E.; Mendes, R.; Raaijmakers, J.M. Impact of plant domestication on rhizosphere microbiome assembly and functions. Plant Mol. Biol. 2016, 90, 635-644. [CrossRef] [PubMed]

14. Hennion, N.; Durandb, M.; Vrieta, C.; Doidya, J.; Maurousseta, L.; Lemoinea, R.; Pourtaua, N. Sugars en route to the roots. Transport; metabolism and storage within plant roots and towards microorganisms of the rhizosphere. Physiol. Plant. 2019, 165, 44-57. [CrossRef] [PubMed]

15. Li, X.Q.; Zhang, D. Gene expression activity and pathway selection for sucrose metabolism in developing storage root of sweet potato. Plant Cell Physiol. 2003, 44, 630-636. [CrossRef]

16. CIP. The International Potato Center. 2019. Available online: https://cipotato.org (accessed on 29 April 2019).

17. El Sheikha, A.F.; Ray, R.C. Potential impacts of bioprocessing of sweet potato: Review. Crit. Rev. Food Sci. Nutr. 2017, 57, 455-471. [CrossRef]

18. Albuquerque, J.R.T.; Ribeiro, R.M.P.; Pereira, L.A.F.; Barros Júnior, A.P.; da Silveira, L.M.; dos Santos, M.G.; de Souza, A.R.E.; Lins, H.A.; Bezerra Neto, F. Sweet potato cultivars grown and harvested at different times in semiarid Brazil. Afr. J. Agric. Res. 2016, 11, 4810-4818.

19. Yasmin, F.; Othman, R.; Sijam, K.; Saad, M.S. Effect of PGPR inoculation on growth and yield of sweet potato. J. Biol. Sci. 2007, 7, 421-424.

20. Sahoo, R.K.; Bhardwaj, D.; Tuteja, N. Biofertilizers: A Sustainable Eco-Friendly Agricultural Approach to Crop Improvement. In Plant Acclimation to Environmental Stress; Tuteja, N., Gill, S.S., Eds.; Springer: New York, NY, USA, 2013; pp. 403-432.

21. Dawwam, G.E.; Elbeltagy, A.; Emara, H.M.; Abbas, I.H.; Hassan, M.M. Beneficial effect of plant growth promoting bacteria isolated from the roots of potato plant. Ann. Agric. Sci. 2013, 58, 195-201. [CrossRef]

22. Nasution, R.A.; Tangapo, A.; Taufik, I.; Aditiawati, P. Comparison of plant growth promoting rhizobacteria (PGPR) diversity and dynamics during growth of Cilembu sweet potato (Ipomoea batatas L var. Rancing) in Cilembu and Jatinangor site, Indonesia. J. Pure Appl. Microbiol. 2017, 11, 837-845. [CrossRef]

23. Radziah, O.; Zulkifli, H.S. Utilization of Rhizobacteria for Increased Growth of Sweet Potato. In Investing Innovation: Agriculture; Food and Forestry; Zaharah, A.R., Ed.; University Putra Malaysia Press: Serdang, Malaysia, 2003; pp. 255-258.

24. Yasmin, F.; Othman, R.; Sijam, K.; Saad, M.S. Characterization of beneficial properties of plant growth-promoting rhizobacteria isolated from sweet potato rhizosphere. Afr. J. Microbiol. Res. 2009, 3, 815-821.

25. Marques, J.M.; da Silva, T.F.; Vollú, R.E.; de Lacerda, J.R.M.; Blank, A.F.; Smalla, K.; Seldin, L. Bacterial endophytes of sweet potato tuberous roots affected by the plant genotype and growth stage. Appl. Soil Ecol. 2015, 96, 273-281. [CrossRef]

26. Alves, R.P.; Blank, A.F.; Oliveira, A.M.S.; Santana, A.D.D.; Pinto, V.S.; Andrade, T.M. Morpho-agronomic characterization of sweet potato germplasm. Hort. Bras. 2017, 35, 525-541. [CrossRef]

27. Sakurai, M.; Wasaki, J.; Tomizawa, Y.; Shinano, T.; Osaki, M. Analysis of bacterial communities on alkaline phosphatase genes in soil supplied with organic matter. Soil Sci. Plant Nut. 2008, 54, 62-71. [CrossRef]

28. Simonet, P.; Grosjean, M.C.; Misra, A.K.; Nazaret, S.; Cournoyer, B.; Normand, P. Frankia genus-specific characterization by polymerase chain reaction. Appl. Environ. Microbiol. 1991, 57, 3278-8326. [PubMed]

29. Poly, F.; Monrozier, L.J.; Bally, R. Improvement in the RFLP procedure for studying the diversity of nifH genes in communities of nitrogen fixers in soil. Res. Microbiol. 2001, 152, 95-103. [CrossRef]

30. Monteiro, J.M.; Vollú, R.E.; Coelho, M.R.R.; Fonseca, A.; Gomes Neto, S.C.; Seldin, L. Bacterial communities within the rhizosphere and roots of vetiver (Chrysopogon zizanioides L. Roberty) sampled at different growth stages. Eur. J. Soil Biol. 2011, 47, 236-242. [CrossRef] 
31. Heuer, H.; Krsek, M.; Baker, P.; Smalla, K.; Wellington, E.M.H. Analysis of actinomycete communities by specific amplification of genes encoding $16 \mathrm{~S}$ rRNA and gel-electrophoretic separation in denaturing gradients. Appl. Environ. Microbiol. 1997, 63, 3233-3241.

32. Kropf, S.; Heuer, H.; Grüning, M.; Smalla, K. Significance test for comparing microbial community fingerprints using pairwise similarity measures. J. Microbiol. Meth. 2004, 57, 187-195. [CrossRef]

33. Hammer, Ø.; Harper, D.A.T.; Ryan, P.D. PAST: Paleontological statistics software package for education and data analysis. Palaeontol. Electron. 2001, 4,9.

34. Lacerda, J.R.M.; da Silva, T.F.; Vollú, R.E.; Marques, J.M.; Seldin, L. Generally recognized as safe (GRAS) Lactococcus lactis strains associated with Lippia sidoides Cham. are able to solubilize/mineralize phosphate. SpringerPlus 2016, 5, 828. [CrossRef]

35. Taketani, R.G.; dos Santos, H.F.; van Elsas, J.D.; Rosado, A.S. Characterisation of the effect of a simulated hydrocarbon spill on diazotrophs in mangrove sediment mesocosm. Antonie Van Leeuwenhoek 2009, 96, 343-354. [CrossRef] [PubMed]

36. Abdel-Razzak, H.S.; Moussa, A.G.; Abd El-Fattah, M.A.; El-Morabet, G.A. Response of sweet potato to integrated effect of chemical and natural phosphorus fertilizer and their levels in combination with mycorrhizal inoculation. J. Biol. Sci. 2013, 13, 112-122. [CrossRef]

37. Mukhongo, R.W.; Tumuhairwe, J.B.; Ebanyat, P.; AbdelGadir, A.H.; Thuita, M.; Masso, C. Combined application of biofertilizers and inorganic nutrients improves sweet potato yields. Front. Plant Sci. 2017, 8, 219. [CrossRef] [PubMed]

38. Oliveira, A.P.; Santos, J.F.; Cavalcante, L.F.; Pereira, W.E.; Santos, M.D.; Oliveira, A.N.; Silva, N.V. Yield of sweet potato fertilized with cattle manure and biofertilizer. Hort. Bras. 2010, 28, 277-281. [CrossRef]

39. Sharma, S.B.; Sayyed, R.Z.; Trivedi, M.H.; Gobi, T.A. Phosphate solubilizing microbes: Sustainable approach for managing phosphorus deficiency in agricultural soils. SpringerPlus 2013, 2, 587. [CrossRef]

40. Yoneyama, T.; Terakado-Tonooka, J.; Minamisawa, K. Exploration of bacterial $\mathrm{N}_{2}$-fixation systems in association with soil-grown sugarcane; sweet potato; and paddy rice: A review and synthesis. Soil Sci. Plant Nut. 2017, 63, 578-590. [CrossRef]

41. Tarafdar, J.C.; Jungk, A. Phosphatase activity in the rhizosphere and its relation to the depletion of soil organic phosphorus. Biol. Fert. Soils 1987, 3, 199-204. [CrossRef]

42. Kandeler, E.; Marschner, P.; Tscherko, D.; Gahoonia, T.S. Nielsen NE. Microbial community composition and functional diversity in the rhizosphere of maize. Plant Soil 2002, 238, 301-312. [CrossRef]

43. Chen, X.; Kou, M.; Tang, Z.; Zhang, A.; Li, H.; Wei, M. Responses of root physiological characteristics and yield of sweet potato to humic acid urea fertilizer. PLOS ONE 2017, 12, e0189715. [CrossRef]

44. Chung, H.; Park, M.; Madhaiyan, M.; Seshadri, S.; Song, J.; Cho, H.; Sa, T. Isolation and characterization of phosphate solubilizing bacteria from the rhizosphere of crop plants of Korea. Soil Biol. Biochem. 2005, 37, 1970-1974. [CrossRef]

45. Hill, W.A.; Bacon-Hill, P.; Crossman, S.M.; Stevens, C. Characterization of $\mathrm{N}_{2}$-fixing bacteria associated with sweet potato roots. Can. J. Microbiol. 1983, 29, 860-862. [CrossRef]

46. Reiter, B.; Bürgmann, H.; Burg, K.; Sessitsch, A. Endophytic nifH gene diversity in African sweet potato. Can. J. Microbiol. 2003, 49, 549-555. [CrossRef] [PubMed]

47. Terakado-Tonooka, J.; Ohwaki, Y.; Yamakawa, H.; Tanaka, F.; Yoneyama, T.; Fujihara, S. Expressed nifH genes of endophytic bacteria detected in field-grown sweet potatoes (Ipomoea batatas L.). Microbes Environ. 2008, 23, 89-93. [CrossRef] [PubMed]

48. Weller, D.M.; Thomashow, L.S. Current challenges in introducing beneficial microorganisms into the rhizosphere. In Molecular Ecology of Rhizosphere Microorganisms: Biotechnology and Release of GMOs; O'Gara, F., Dowling, D.N., Boesten, B., Eds.; VCH: New York, NY, USA, 1994; pp. 1-18.

(C) 2019 by the authors. Licensee MDPI, Basel, Switzerland. This article is an open access article distributed under the terms and conditions of the Creative Commons Attribution (CC BY) license (http://creativecommons.org/licenses/by/4.0/). 